\title{
Forest certification in Canada: An exploratory study of perceptions of provincial and territorial government employees
}

\author{
by Anna V. Tikina ${ }^{1,2}$, Robert A. Kozak ${ }^{3}$, John L. Innes ${ }^{1}$, Peter N. Duinker ${ }^{4}$ and Bruce C. Larson ${ }^{1}$
}

\begin{abstract}
This article provides a review of the governmental approaches to forest certification and of the applicability of forest certification requirements across Canada. Surveys of Canadian provincial and territorial government employees were conducted to examine their views about the rise of non-governmental governance in the form of forest certification. Respondents perceived that forest certification has had a positive effect on many aspects of forest management. The most prominent effects of certification from their perspectives were improved market access, increased monitoring, better emergency preparedness, and the creation of a mechanism by which corrective measures can be applied to remedy issues.
\end{abstract}

Key words: forest certification, governance, regulation, effectiveness, perceptions

\section{RÉSUMÉ}

Cet article constitue une revue des approches suivies par les gouvernements en matière de certification forestière et d'applicabilité des exigences liées à la certification forestière partout au Canada. Un sondage auprès de fonctionnaires provinciaux et territoriaux de tout le Canada a été réalisé dans le but d’établir leurs perceptions de lessor de cette gouvernance non-gouvernementale que semble être la certification forestière. Les réponses indiquent la perception d'un effet positif engendré par la certification forestière sur plusieurs aspects de l'aménagement forestier. Les principaux impacts de la certification selon leurs points de vue se reflètent dans un accès plus facile des marchés, des suivis accrus, une meilleure préparation en cas d'urgence et la création d'un mécanisme selon lequel des mesures correctives peuvent être appliquées pour résoudre des problèmes.

Mots clés : certification forestière, gouvernance, réglementation, efficacité, perceptions

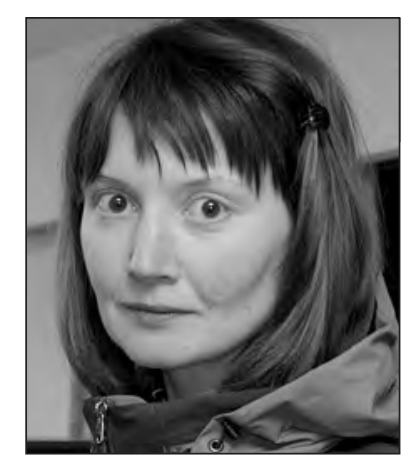

Anna V. Tikina

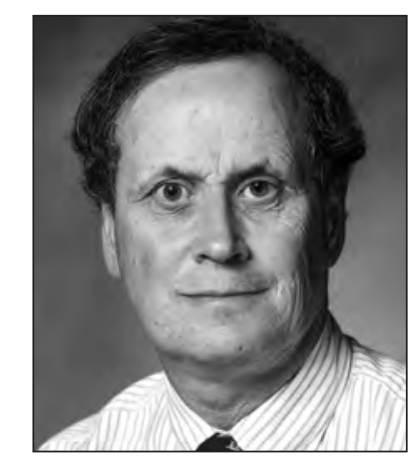

Bruce C. Larson

Robert A. Kozak

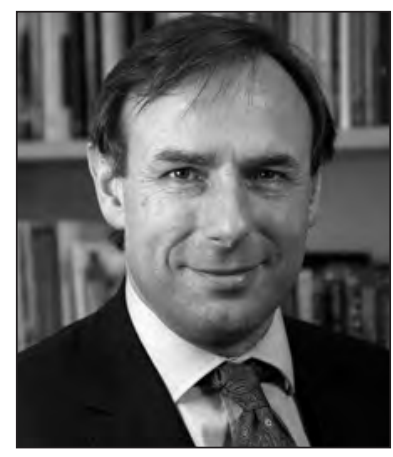

John L. Innes

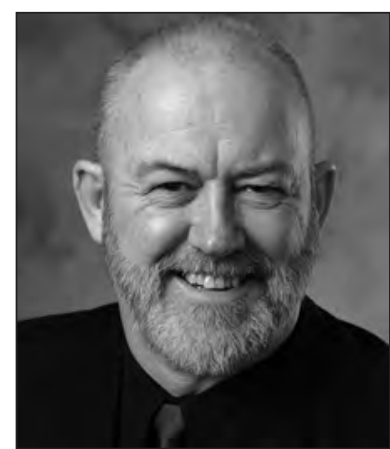

Peter N. Duinker

\footnotetext{
${ }^{1}$ Forest Resources Management Department, Faculty of Forestry, University of British Columbia, 2045-2424 Main Mall, Vancouver, British Columbia V6T 1 Z4.

${ }^{2}$ Corresponding author. E-mail: anna.tikina@ubc.ca

${ }^{3}$ Wood Science Department, Faculty of Forestry, The University of British Columbia, 4040-2424 Main Mall, Vancouver, British Columbia V6T $1 Z 4$.

${ }^{4}$ School for Resource and Environmental Studies, Faculty of Management, Dalhousie University, 6100 University Avenue, Suite 5010, Halifax, Nova Scotia B3H 3J5.
} 


\section{Introduction}

When forest certification emerged in the mid-1990s, it became a tool to improve forest management and address the environmental, social, and economic externalities of forestry (Upton and Bass 1996, Vogt et al. 2000, Cashore et al. 2004). The focus of the discussion lay in the market pressure that could drive non-certified forest products out of certain markets (Hansen 1997, Fletcher et al. 2002). More recently, however, it has become evident that forest certification has developed into a governance mechanism (Cashore 2002, Bernstein and Cashore 2004, Gulbrandsen 2004, Overdevest and Rickenbach 2006, Tollefson et al. 2008). Since the inception of forest certification in the mid-1990s, Canada has joined the "certification race", becoming a world leader in the area of certified forests ${ }^{5}$. Three voluntary forest certification schemes have been widely applied in Canada: Canadian Standards Association (CSA Z809), Sustainable Forestry Initiative (SFI), and Forest Stewardship Council (FSC).

Governmental participation in a voluntary environmental program is measured by the level of engagement (UNECE/FAO 2005) and can vary within a spectrum of "observing-cooperating-enabling-endorsing-mandating" for the applicable certification program within a jurisdiction (Lister 2009). Carey and Guttenstein (2008) differentiated three groups of governmental approaches to voluntary programs: "users" (directly involved in the program), "supporters" (provide incentives to the program), and "facilitators" (provide resources to help with the development and implementation of the program). These groups also broadly overlap with the system suggested by Rametsteiner (2002), who considered that the role of governments in forest certification includes: 1) design and implementation of the sustainable forest management (SFM) standards, 2) assistance in the development and application of forest certification standards, and 3) provision of market incentives for certified companies.

Since forest certification evolved as a part of the international environmental regime, the Canadian federal government has consistently shown its support (Fraser 2007). In fact, the Canadian federal government has participated in the first two activities identified by Rametsteiner (2002). A case in point is the criteria and indicator processes that took place in Canada. Beyond the internationally developed Montreal Criteria and Indicators, the development of the national criteria and indicators adopted by the Canadian Council of Forest Ministers (CCFM) constituted a significant step taken aimed at SFM across the country (CCFM 2005). Governments also sent their representatives and observers to attend certification development boards and committees (Lister 2009), thus providing assistance in the development and operation of certification standards. Tollefson et al. (2008) provided evidence that even FSC's position to minimize government involvement in standards development had softened to allow government officials to participate in the standards setting, thus bringing their expertise to several jurisdictions. However, the market or administrative incentives provided by the respective governments to certified companies have been limited to imposing certain requirements on their suppliers (Lister 2009).

\footnotetext{
${ }^{5}$ http://www.certificationcanada.org/english/status_intentions/status.php
}

Existing Canadian procurement requirements have involved a commitment from the Public Works and Government Service Canada to achieve LEED (Leadership in Energy and Environmental Design) Gold standard certification for leased or owned public buildings (Government of Canada 2010). Although this commitment does not translate into direct promotion of forest certification, the points-based nature of the LEED system means that wood products certified by an FSC standard contribute, in a very minor way, to certification under the LEED standard. While it will be interesting to see if the LEED system will be modified to give more points for the use of certified products, at present it only awards a single point for certified wood products, and unlike other green building standards around the world, the point is only given for certification to a particular scheme (FSC). As a result, LEED can currently offer more points for locally produced wood products than for certified wood (U.S. Green Building Council 2009).

Besides federal initiatives, provincial governmental commitments to forest certification have also emerged. Ontario has a requirement to source products for governmental offices from suppliers with environmentally sustainable production practices (Ontario Ministry of Finance 2009). The province has also developed its own criteria and indicators of SFM (Miller and Nelson 2003). In addition to this general trend toward sustainability, Ontario and New Brunswick have required that licensees operating on Crown land be certified (Communications New Brunswick 2002, OMNR 2004), while Prince Edward Island has decided to pursue FSC certification for Crown land (Government of Prince Edward Island 2010). Quebec has made some commitments and steps toward mandating certification on Crown land (Lister 2009, MRNFQ 2010). The Government of British Columbia has indicated its support and adoption of forest certification by its commitment to certify at least $75 \%$ of the forest operations conducted by the Crown Corporation, BC Timber Sales, to CSA or SFI standards (BC Timber Sales n.d.). Some provinces have considered or held pilot co-audits to combine thirdparty certification with governmental programs for compliance and enforcement (Cafferata et al. 2002, NBDNR 2004, Ramsay 2004), thus limiting the expenditures for audits by governments and those being audited.

Several studies have investigated different aspects of governmental attitudes towards forest certification around the globe (Vlosky 2000; Cashore 2002; Cashore et al. 2003a, 2006; Gulbrandsen 2004, 2005; Hickey et al. 2005, 2007; May 2006; Auld et al. 2008; Ebeling and Yasue 2009) and in Canada (Gale 2002, Gale and Gale 2006, Bourgeois et al. 2007, Fraser 2007, Howlett et al. 2009, Lister 2009). Our study first provides a review of the applicability of forest certification schemes across Canada, followed by an assessment of governmental perceptions on the effects of certification.

\section{"Hard Law" vs. Forest Certification in Canada}

The effectiveness of voluntary mechanisms, such as forest certification, is often compared to the effects of "hard law" (existing laws and regulations) (Snyder 1993, Abbott and Snidal 2003, Hickey 2004). Proponents of voluntary, "soft law" mechanisms (e.g., Smart 1992, Aurora and Cason 1996, Nash and Ehrenfeld 1997, Prakash 1999, Bernstein and Cashore 2004, Ice et al. 2004, Potoski and Prakash 2004, 
Marshall et al. 2005) advocate the flexibility, cost-efficiency, and outcomes of "soft law" programs. These arguments are also relevant to forest certification. Forest certification as a voluntary mechanism (or "soft law") can supplement governmental requirements and offer greater environmental protection (Cashore 2002, Bernstein and Cashore 2004). However, there is evidence that not only do voluntary standards affect each other (Cashore et al. 2004), but that legal and regulatory requirements also change with the impact of "soft laws" (Skjærseth et al. 2006), although the extent of such influences varies. On the other hand, forest certification can impose additional financial burdens and highlight the discrepancies of economies of scale without generating any significant impacts on environmental conditions (Haener and Luckert 1998, Klingberg 2003, Leslie 2004, Tikina 2008), particularly where existing forest and environmental legislation is comprehensive and enforced.

In Canada, forest certification standards rely on provincial and federal laws and regulations in many ways. All standards require compliance with the legal and other requirements (such as voluntary codes of practice) that exist within a jurisdiction. The CSA and SFI assume compliance with or going beyond the requirements of all laws and regulations applicable to the forest area under review, whereas the FSC requires compliance with or exceeding all laws (Table 1). By "applicable", CSA and SFI refer to forestry-related, environmental, and social laws and, in the case of SFI, may include laws for business performance (SFI 2010a).

\section{Compliance with international agreements}

FSC standards require compliance with certain international agreements (Criterion 1.3.), including both those ratified by Canada and those where Canada is not a signatory (FSCCanada 2004). The ratified documents include: Framework Convention on Climate Change, Convention on Biological Diversity, Convention on International Trade in Endangered Species, Convention for the Protection of the World Cultural and Natural Heritage, Ramsar Convention on Wetlands of International Importance, especially as Waterfowl Habitat, Migratory Birds Convention, and International Labour Organization (ILO) Conventions 87, 98, 100, 111, 131, and 155. Besides these, FSC also requires compliance with ILO Conventions 29, 97, 105, 138, 141, 142, 143, 169, and 182, and ILO Code of Practice on Safety and Health in Forestry Work.

The CSA Z809-2008 standard also requires compliance with ILO Convention 87 "Freedom of Association" and 98 "Protection of the Right to Organize". Another CSA requirement pertains to the SFM policy that a company develops; the policy must contain commitments to honour all international agreements and conventions signed by Canada, although no specification is given as to what actions suffice for fulfilling such commitments. The CSA standard also emphasizes that the CCFM Criteria that serve the basis for the standards' performance requirements are consistent with the international Helsinki and Montreal processes.

The newly-adopted 2010-2014 SFI standard refers to core ILO Conventions 87 and 98 (like CSA) and also Convention

Table 1. Approaches of certification schemes on the use of legal and regulatory requirements

\begin{tabular}{|c|c|c|c|}
\hline & CSA 2008 & SFI 2010 & FSC \\
\hline Applicability & $\begin{array}{l}\text { National standard for Canada } \\
\text { Requires development of local/ } \\
\text { regional values, objectives, } \\
\text { indicators, and targets }\end{array}$ & $\begin{array}{l}\text { One standard for USA and } \\
\text { Canada } \\
\text { A few requirements to address } \\
\text { regional programs and issues }\end{array}$ & $\begin{array}{l}\text { Four regional standards: } \\
\text { - FSC-BC } \\
\text { - FSC-Boreal } \\
\text { - FSC-Maritimes } \\
\text { - draft FSC- Great Lakes- } \\
\text { St. Lawrence }\end{array}$ \\
\hline Compliance with legal & Yes & Yes & Yes \\
\hline
\end{tabular}

requirements

Exceeding legal and other requirements

Extending compliance to contractors and suppliers

Reference to applicable international agreements

References to specific legislation and BMPs in the standards

Possibly conflicting requirements No between standard and legal compliance
Mentioned with regard to SFM policy development

Not explicitly mentioned

Potentially included as parties necessary to address the SFM elements for the DFA

Yes

General requirement to comply

Requirement to respect legal rights and responsibilities of other parties, including Aboriginal and treaty rights
Mentioned with regard to water quality

Yes

Yes

General requirement to comply

BMPs are referenced for certain values

No
Mentioned with regard to health and safety of employees and their families

No

Yes

Standards include reference to applicable laws and regulations 
111 "Discrimination" (SFI 2010a,b), as they are "not fully covered by existing U.S. or Canadian law" (Sustainable Forestry Initiative 2010b). The SFI generally limits its applicability to "federal, provincial, state, and local laws and regulations" (SFI 2010a) based on the assumption that, if an international agreement requires an action, the government will have legislated it and, therefore, there is no reason to repeat a compliance requirement for each individual requirement in the standard.

\section{Explicit references to legal and regulatory compli- ance}

The three certification systems differ in how they use legal and regulatory compliance (Table 1). The FSC system includes several regional standards containing a section that refers to laws and regulations in the respective regions. As the SFI and CSA schemes apply across Canada, they imply compliance with applicable federal documents, as well as with the relevant legal and regulatory requirements in the province or territory in which the entity pursuing certification is located. The CSA standard refers to legal and other requirements in SFM Requirements (7.3.3 Rights and Regulations), but, like the SFI Standard, does not provide a specific list of legally binding documents. The SFI includes references to legal compliance in its Principles for Sustainable Forestry (8. Legal Compliance) and Objective 11 (Commitment to Legal Compliance) of the standard.

In the text of the SFI standard, several statements can also be found on best management practices (BMPs). The BMPs can be legally adopted or voluntary and are defined in SFI as "a practice or combination of practices that is determined by a federal, provincial, state, or local government or other responsible entity, after problem assessment, examination of alternative practices, and appropriate public participation, to be the most effective and practicable (including technological, economic, and institutional considerations) means of conducting a forest management operation while addressing any environmental considerations" (Sustainable Forestry Initiative Program 2005). BMPs in the Canadian setting can refer to procedures described in non-legally-binding guidebooks or manuals. In the SFI standard, BMPs are referenced with respect to chemical application (Performance Measure 2.2, Indicator 6), water quality programs (Performance Measure 4.1.3.1.1.), riparian protection (Performance Measure 3.1, Indicator 1), soils (Performance Measure 3.2, Indicator 2), and procurement programs (Objective 8). Through SFI Objective 8 , the requirements on BMP compliance are extended to suppliers and contractors.

Each of the certification schemes takes a different approach on regional applicability of the standards, and this has raised some concerns. The SFI and CSA standards are applicable across Canada without regional differentiation. Although objectives and indicators are set locally under the CSA standards, the broad national approach leads to the argument that forest legislation in some regions can be significantly more stringent than in others. On the other hand, the FSC approach takes into consideration differences in regional legislation, but this has created problems by having inequitable requirements on adjacent lands in separate regions (Cashore et al. 2003b). Applying the same standard to all regions simultaneously (e.g., like CSA across Canada) provides an advantage to certified companies in regions with less stringent legislation; they receive the same market recognition that arguably comes from being certified as the companies in highly regulated regions, but their costs of compliance are lower because stricter legislation imposes higher costs on forest management (Gale and Gale 2006). On the other hand, advanced forest practices in regions with more stringent legislation may lead to a situation where fewer changes are needed if an entity decides to pursue certification in this region (Fletcher et al. 2001), thus decreasing expenditures. Within the FSC setting, this also could mean discrepancies between legal and certification requirements and, therefore, a greater potential for conflicting requirements and a need for conflict resolution.

\section{Objectives and Scope}

All certification standards used in Canada rely on governmental regulation to a certain extent. We investigated how the Canadian government treats forest certification and whether governmental employees perceive certification to be a reliable means of regulating forest management. The overall goal of the study was to assess the perceptions of provincial and territorial government employees across Canada on the effectiveness of forest certification. The aspects in the framework for assessing the effectiveness of forest certification (Tikina and Innes 2008) include identified changes in behaviours of parties involved in forest certification, as well as the acceptance and adoption of forest certification by governmental employees. Hence, the opinions of governmental employees were sought on both aspects, i.e., changes in behaviours related to forest certification and the adoption of the mechanism.

Data were collected in the summer of 2008. The study covered all provinces and territories except Nunavut, because of marginal relevance of forest certification in that territory. The assessment was limited to forestry and natural resource management specialists within the government, at both the district and regional levels. These two levels of employees were assessed based on the assumptions that district employees may be better positioned to note on-the-ground effects, while officials at the regional level can provide opinions on more strategic issues dealing with forest certification. Employees of the federal government were not surveyed, given their limited jurisdiction over land and resource management within provinces and territories, as well as the absence of certified federal forest operations.

\section{Methods}

The Tailored Design Method (Dillman 2000) was used to design and administer the survey. The mailing list for the sample was compiled through an online search of directories of forestry and natural resource management employees. The database contained mailing addresses and, where possible, email addresses. Those whose email addresses were accessible received an e-mail invitation to participate in the study and a link to the online survey. The rest were sent a paper version of the survey package, which contained a cover letter describing the study and its objectives, the survey, and a return envelope. In Saskatchewan, the only province where both online and paper versions of the survey were sent, it was not possible to ensure that the same person did not return both versions; however, this possibility is unlikely given the typically busy schedule of government employees. A reminder letter was 
sent two weeks later, and a replacement survey was sent to the sample four weeks after the first mailing. From the total mailing list, 226 surveys were sent by mail and 111 invitations to fill out an online survey were sent by email, for a total sample frame of 337 government employees in forestry and/or natural resources regions and districts.

The survey collected general information about the region/ district that the respondent works in/oversees. Further questions focused on respondents' perceptions of the effects of forest certification on forest management; respondents were asked to rate the extent of change in various forest management practices (both in forest industry operations and in the operations of government forestry enterprises) that came about as a result of forest certification. The list of practices where change could potentially occur was developed based on the requirements of all three forest certification systems. The list was divided into four sections: economic, social, environmental, and management systems. Respondents were asked to rate the changes from " 3 " (major improvement) to “ 3 " (major deterioration), with " 0 ” indicating no change. The mean scores of changes associated with each practice (with 95\% confidence intervals) were later analyzed for each section. The survey also asked about the benefits of forest certification for governments and stakeholders within the jurisdiction of the respondent and also sought recommendations on how forest certification could be improved. A free-form comments section concluded the survey.

The handling of the survey was contracted out, and the contractor's procedures made it impossible to separate early from late responses, meaning that non-response bias could not be tested (Armstrong and Overton 1977). Caution is, therefore, warranted when interpreting the results. That said, the trends noted in this survey were comparable to patterns recorded in similar studies (Rametsteiner 2002, Lister 2009) and are, therefore, likely to be representative of the opinions of government employees. The distributions of the sample frame and the responses by province/territory (Table 2) were likewise similar, indicating the probable absence of the nonresponse bias.

\section{Results and Discussion}

Overall, 64 surveys out of 337 were returned and considered usable, for a response rate of $19 \%$. These responses included both paper returns (46 responses) and the online version (18 responses) (Table 2). The greatest number of responses was received from British Columbia (23\% of all respondents; $\mathrm{n}=$ $15)$ and Ontario $(22 \% ; n=14)$. No responses were received from Manitoba or Prince Edward Island.

\section{Adoption and perceptions of forest certification}

Several questions related to governmental attitudes towards forest certification, perceptions of its effects, and overall adoption levels. When describing the situation with forest certification in their respective jurisdictions, 17 respondents (26\%) indicated that forest certification is a requirement by the provincial/territorial government. These responses were solely from Ontario and New Brunswick, where the government has already mandated forest certification on public lands. Seven additional respondents (13\%) indicated that governmental plans exist for mandating adherence to forest certification. These responses came from Quebec, Saskatchewan, British Columbia, and Newfoundland (there
Table 2. Summary of responses from Canadian provinces/ territories

\begin{tabular}{|c|c|c|c|c|}
\hline Jurisdiction & Sent & Received & $\begin{array}{c}\text { Percent } \\
\text { returned } \\
(\%)\end{array}$ & Method \\
\hline Alberta & 28 & 3 & 11 & Paper \\
\hline British Columbia & 32 & 15 & 47 & Paper \\
\hline Quebec & 52 & 9 & 17 & Paper \\
\hline Manitoba & 8 & 0 & 0 & Online \\
\hline New Brunswick & 31 & 3 & 10 & Online \\
\hline Newfoundland & 19 & 6 & 32 & Paper \\
\hline Nova Scotia & 31 & 2 & 6 & Online \\
\hline Northwest Territories & 9 & 1 & 11 & Online \\
\hline Ontario & 45 & 14 & 31 & Paper \\
\hline Prince Edward Island & 5 & 0 & 0 & Online \\
\hline Saskatchewan & 65 & 9 & 14 & $\begin{array}{c}\text { Online (15) } \\
\text { and paper (50) }\end{array}$ \\
\hline Yukon Territory & 12 & 2 & 17 & Online \\
\hline Overall & 337 & 64 & 19 & \\
\hline
\end{tabular}

are currently discussions on making forest certification a governmental requirement in Quebec, but not in any of the other provinces that answered this question affirmatively). A number of government-owned forest operations (e.g., BC Timber Sales n.d.) have become certified in British Columbia, Ontario, Quebec, and Saskatchewan, and plans exist to certify more of them across the country, indicating that forest certification is generally viewed positively by the governments.

The survey identified the presence of certified forest companies on public lands in the majority of provinces. Respondents cited the presence of all certification systems; CSA-, SFI-, and FSC-certified companies were all represented, thus allowing our analysis to apply to all three schemes. The roles of government in the development and application of forest certification strategies were also assessed. As it was possible that governments were adopting more than one strategy towards certification, respondents were given the opportunity to select all possible answers that reflected their governments' attitudes when answering these questions. The most common attitudes noted were as follows: encouragement of the use of certification ( $25 \%$ of responses; $\mathrm{n}=15)$, "wait and see" approaches $(14 \% ; n=8)$, mandating forest certification (14\%; $\mathrm{n}=8$ ), and assisting in general capacity-building for the sector in the province/territory $(13 \% ; \mathrm{n}=7)$ (Fig. 1).

As Ontario and New Brunswick require major forest licensees to obtain certification, the likelihood of responses about mandatory forest certification was highest from these provinces. A few trials have been carried out in British Columbia and Ontario that combine forest certification audits and government compliance and enforcement inspections (Cafferata et al. 2002, Brownie and Edquist 2004), and this was also reflected in the data. To date, the majority of provincial/territorial governments have viewed forest certification positively and, if they have not mandated its adoption, they have either encouraged the forest industry to use certification or participated in discussions on certification and its development. Provisions of in-kind support have also been common. 


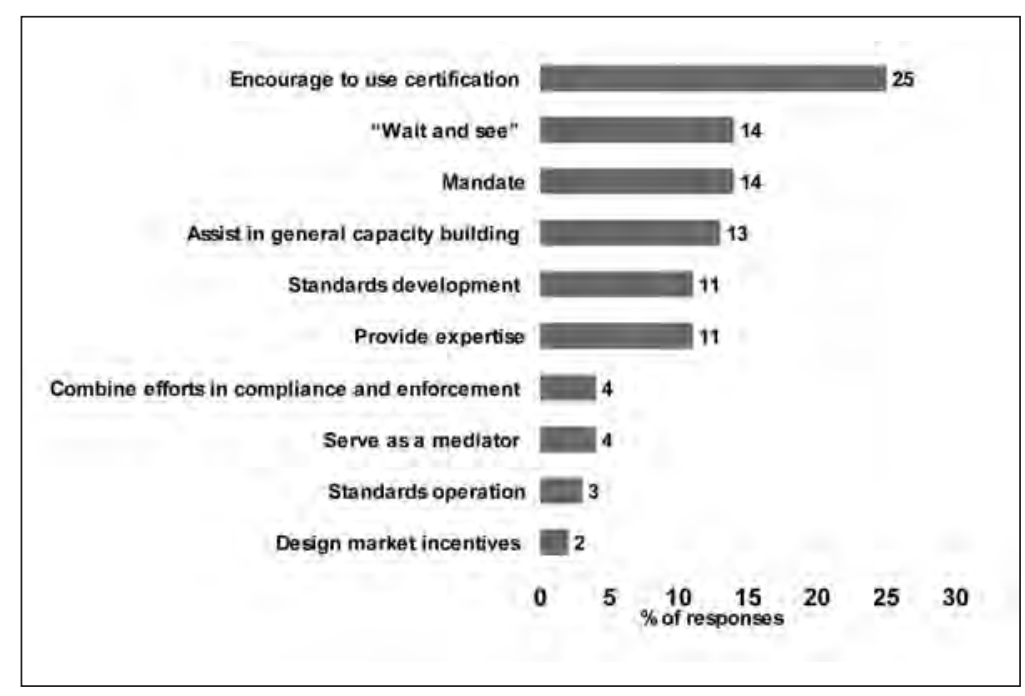

Fig. 1. General government attitudes to forest certification by percentage of responses ( $n=114$ ).

By being adopted as a governmental requirement, certification has gained greater process effectiveness (Tikina and Innes 2008), regardless of the scheme used. However, mandating all forest entities to become certified negates the (thus far) limited potential opportunities for price premiums on certified products. This effectively "levels the field" for forest companies operating in one jurisdiction, without giving them a competitive edge through possible market advantages. When competing with companies from jurisdictions without mandatory forest certification, certified companies are disadvantaged in that they are forced to absorb the costs of certification, thus increasing operational costs. While all major forest companies are certified in Canada, there are a number of smaller forest companies that have avoided committing to certification, and thus may have the advantage in "non-mandating" jurisdictions.

\section{Perceived impacts of forest certification}

Sixty-six percent of the respondents suggested that changes in forest management had occurred as a result of forest certification, both in forest industry operations and in the operations of the government forestry enterprises. The mean scores of changes associated with each practice (with 95\% confidence intervals) are presented on separate graphs (Fig. $2 \mathrm{a}-\mathrm{d}$ ) and generally tend to show small positive changes as a result of forest certification.

The majority of the means indicate that forest certification was perceived as improving forest practices. However, this was not the case for local employment, which was the only mean value to have a negative score. However, it is impossible to conclude that governments perceived a loss in local employment associated with forest certification as the width of the confidence interval precludes such inference. Most improvements were found in management-systems aspects; certification was perceived to improve monitoring systems and emergency preparedness procedures resulting in the correction of non-compliances found by either government or certification audits. For economic aspects, market access was viewed as the most prominent improvement. Market access has been the driver for forest certification since its inception (Upton and Bass 1996, Vogt et al. 2000, Fletcher et al. 2002), especially in regions that are sensitive to environmentally responsible performance (e.g., Europe) (IBM Business Consulting Services 2003, Archer et al. 2005, Owari et al. 2006). This study supports the idea that the forest industry is not the only sector actor that views market access as a major benefit of forest certification (Aguilar and Vlosky 2007); government employees did as well. As for the United States - the major importer of Canadian wood products-forest certification has not played a significant role in ameliorating access of Canadian wood to U.S. markets in relation to the requirements of the amended Lacey Act in the U.S. Although not a sufficient condition to avoid the requirements of import declarations that are laid out by the Act, it has, however, provided an approach to "due care" with respect to the avoidance of illegal logging (Environmental Investigation Agency and World Resources Institute 2009). Nonetheless, non-state governance in the form of forest certification has become a business standard for large forest companies operating in Canada, who use it to maintain market access through improved company image (Chen et al. 2009).

Results pertaining to the social aspects of certification showed the most uncertainty with the range of responses and associated confidence intervals being much larger than for other aspects. This possibly implies a lesser understanding of this aspect by the respondents given that the target audience was drawn from natural resource specialists, or that environmental, economic, and systems-management matters receive greater emphasis in voluntary programs in the forest sector (Vidal and Kozak 2008), meaning that social aspects tend to be less developed. The greatest improvement was perceived to be improvements in communications among stakeholders.

Approximately $80 \%(n=53)$ of the respondents saw benefits being derived from forest certification. The respondents were asked to describe these benefits in an open-ended question, and their comments were analyzed to uncover common themes. Several themes received greater attention from the respondents, such as improved market access $(17 \% ; n=18)$, public relations $(16 \% ; n=17)$, forest practices $(15 \% ; n=16)$, and legal compliance $(12 \% ; \mathrm{n}=13)$. Other benefits mentioned included the better organization of records and processes, increased credibility of forest management, increased competitiveness for the industry, and increased awareness of SFM.

Almost half $(\approx 46 \%, \mathrm{n}=30)$ of the respondents also saw some drawbacks in forest certification-considerably less than those who saw benefits. The issue mentioned most often $(n=14)$ was the high or increased cost of operations. This was followed by the problem of conflicting governmental and certification requirements $(\mathrm{n}=8)$, which is only possible for FSC certification as it allows for divergence of legal and certification requirements. Other themes uncovered in the comments on the drawbacks of forest certification included added bureaucracy and workloads, limited market recognition for certified products, and unrealistic expectations of certification.

Those who saw potential for improvements to the forest certification process and its outcomes suggested that forest certification would benefit most if a larger proportion of the 


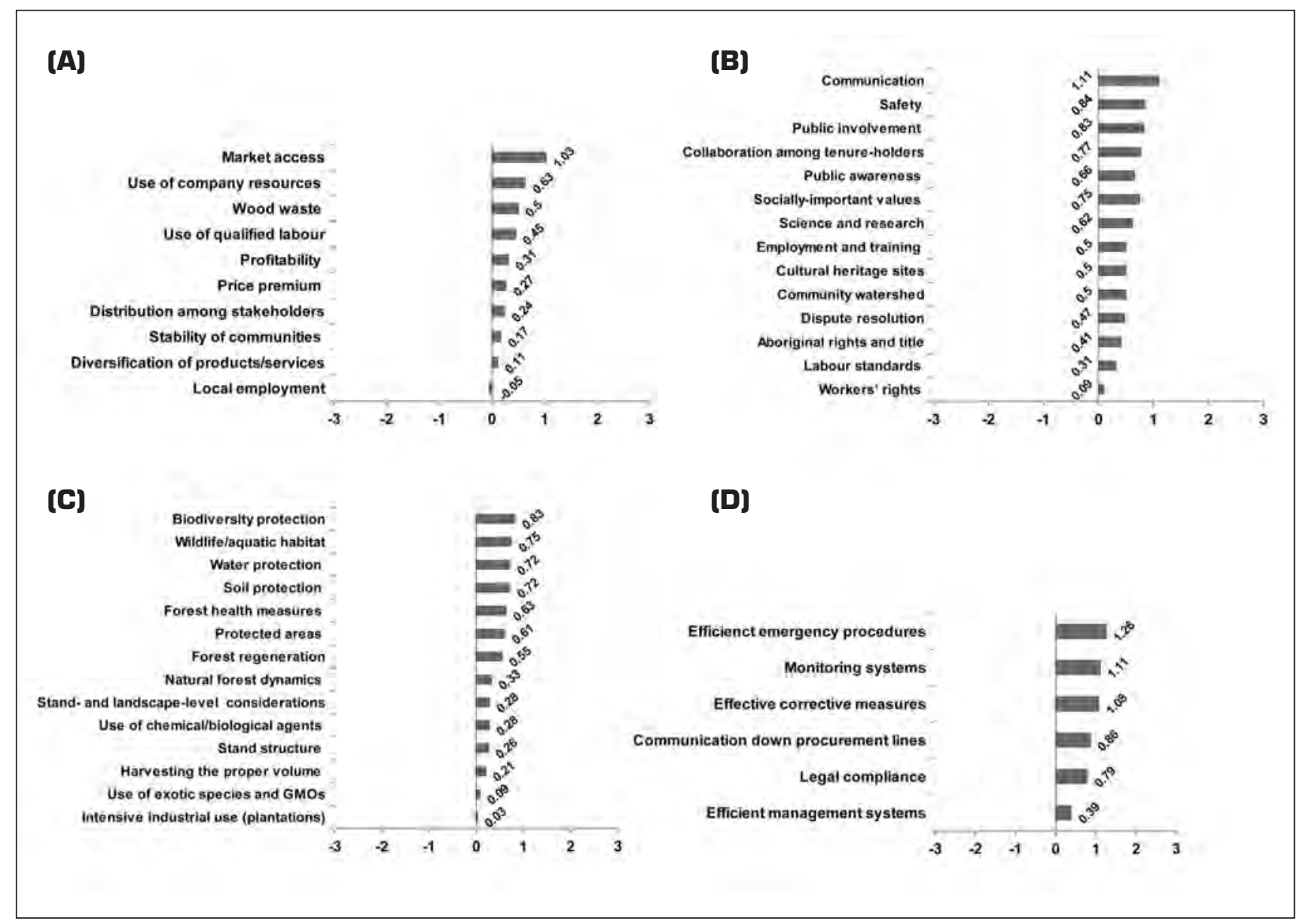

Fig. 2. - (a) Mean perceived changes in economic aspects of forest practices $(-3=$ major deterioration; $0=$ no change; $3=$ major improvement), (b) Mean perceived changes in social aspects of forest practices ( $-3=$ major deterioration; 0 = no change; $3=$ major improvement), (c) Mean perceived changes in environmental aspects of forest practices ( $3=$ major deterioration; $0=$ no change; $3=$ major improvement), (d) Mean perceived changes in management-system aspects of forest practices ( $3=$ major deterioration; $0=$ no change; 3 = major improvement].

general public were made aware of it and accepted certification as a valid mechanism for describing SFM. However, unlike European governments (Steurer et al. 2007), Canadian governments have refrained from adopting tangible incentives for forest certification (UNECE/FAO 2005) and, therefore, have not engaged in campaigns aimed at educating the general public about the effects of forest certification and its relation to SFM. Respondents saw this as one of the factors explaining why the general public was generally unaware of forest certification.

Although FSC places great emphasis on its on-the-ground application and, thus, distances itself from other standards, the respondents' suggestion to place a greater focus on the practices on-the-ground applied to all three certification schemes. This suggestion also raises questions surrounding the resources required for forest certification. If certification remains a major bureaucratic exercise, perhaps the resources required would be better used if allocated elsewhere. However, if government employees indeed perceived an improvement in forest management related to forest certification efforts, then it is surprising that the government has not promoted forest certification to a greater extent.

\section{Conclusion}

Forest certification has gained legitimacy and support from Canadian governments at both the federal and provincial/ territorial levels, although few governments have adopted direct ways of supporting certification, such as mandating forest certification for forestry operations on Crown land. This survey of provincial/territorial government employees' perceptions of the effects of forest certification revealed that most changes brought about by forest certification in social, environmental, economic, and management realms were viewed as being positive. The most prominent effects of certification were reported to be improved monitoring, better emergency preparedness, and the application of corrective measures after an issue in forest management has been discovered. Government employees also perceived that certification improved communications among stakeholders and allowed companies to maintain (or gain) market access.

Legitimizing forest certification through certifying government-owned forest operations and encouraging forest companies to use certification are signs that governmental employees have viewed forest certification as an effective mechanism to achieve SFM. Although forest certification is 
considered a form of non-governmental governance, there was no evidence to suggest that government employees considered certification to be supplanting the role of government within the forestry governance domain. Equally, there was no indication that government employees have linked certification with reduced government oversight. Forest certification, in most jurisdictions, was still considered to be a voluntary measure adopted by companies, and governments were not offering any incentives, for example, to reduce the administrative burdens for companies adopting certification.

\section{References}

Abbott, K.O.W. and D. Snidal. 2003. Hard and soft law in international governance. International Organization 54(03): 421-456.

Aguilar, F.X. and R.P. Vlosky. 2007. Consumer willingness to pay price premiums for environmentally certified wood products in the U.S. Forest Policy and Economics 9(8): 1100-1112.

Archer, H., R. Kozak and D. Balsillie. 2005. The impact of forest certification labelling and advertising: an exploratory assessment of consumer purchase intent in Canada. The Forestry Chronicle 81(2): 229-244.

Armstrong, J. S. and T.S. Overton. 1977. Estimating nonresponse bias in mail surveys. Journal of Marketing Research 14(3): 396-402. Auld, G., L.H. Gulbrandsen and C.L. McDermott. 2008. Certification schemes and the impacts on forests and forestry. Annual Review of Environment and Resources 33(1): 187-211.

Aurora, S. and T.N. Cason. 1996. Why do firms volunteer to exceed environmental regulations? Understanding participation in EPA's 33/50 program. Land Economics 72(4): 413-432.

BC Timber Sales. n.d. Sustainable forest management (SFM) certification [online]. Available at http://www.for.gov.bc.ca/BCTS/forest Certification/sfm_certification.htm.

Bernstein, S. and B. Cashore. 2004. Non-state global governance: is forest certification a legitimate alternative to a global forest convention? In J. Kirton and M. Trebilcock (eds.). Hard choices, soft law: voluntary standards in global trade, environment and social governance. pp. 33-63. Ashgate Press, Aldershot, UK.

Bourgeois, L., D. Kneeshaw, L. Imbeau, N. Belanger, S. Yamasaki and S. Brais. 2007. How do Alberta's, Ontario's and Quebec's forest operation laws respect ecological sustainable forest management criteria in the boreal forest? The Forestry Chronicle 83(1): 61-71.

Brownie, K. and K. Edquist. 2004. Compliance audits and certification. The Frontiers of Forest Certification. Fifth Certification Watch Conference. Training workshop, Vancouver, BC.

Cafferata, B., D. Dahl, S. Hughes and J. Waldorf. 2002. Role of an independent forestry watchdog in an era of certification. Forest Practices Board of British Columbia. Third Certification Watch Conference. Vancouver, BC.

[CCFM] Canadian Council of Forest Ministers. 2005. Criteria and indicators of sustainable forest management in Canada [online]. Available at http://www.ccfm.org/ci/rprt2005/English/toc.htm.

Carey, C. and E. Guttenstein. 2008. Governmental use of voluntary standards: Innovation in sustainability governance. London, UK, ISEAL Alliance. Available at http://www.fabricaethica.it/documenti/795.private\%20standard__Innovation_in_Sustainability_ Governance.pdf.

Cashore, B. 2002. Legitimacy and the privatization of environmental governance: how non-state market-driven (NSMD) governance systems gain rule-making authority. Governance: An International Journal of Policy, Administration, and Institutions 15(4): 503-529.

Cashore, B., G. Auld and D. Newsom. 2003a. Forest certification (eco-labeling) programs and their policymaking authority: explaining divergence among North American and European case studies. Forest Policy and Economics 5: 225-247.

Cashore, B., G. Auld and D. Newsom. 2003b. The United States' race to certify sustainable forestry: non-state environmental gover- nance and the competition for policy-making authority. Business and Politics 5(3): 219-259.

Cashore, B., G. Auld and D. Newsom. 2004. Governing through markets: forest certification and the emergence of non-state authority. Yale University Press, New Haven, CT. 352 p.

Cashore, B., F. Gale, E. Meidinger and D. Newsom (eds.). 2006. Confronting sustainability: Forest certification in developing and transitioning countries. Yale University Press, New Haven, CT. 622 p. Chen, J., A. Tikina, J. Innes, B. Larson, R. Kozak and P. Duinker. 2009. Efficacy of forest certification in Canadian forest industry perceptions. Poster presented at SFMN Conference "Envisioning Tomorrow's Forests", Gatineau, QC, April 2009.

Communications New Brunswick. 2002. Forest certification to be implemented on Crown land by 2003 [online]. Available at http://www.gnb.ca/cnb/news/nr/2002e0341nr.htm.

Dillman, D. A. 2000. Mail and internet surveys. John Wiley \& Sons, Inc., New York. 862 p.

Ebeling, J. and M. Yasue. 2009. The effectiveness of market-based conservation in the tropics: Forest certification in Ecuador and Bolivia. Journal of Environmental Management 90(2): 1145-1153.

Environmental Investigation Agency and World Resources Institute. 2009. Are you ready for the Lacey Act? World Resources Institute, Washington, DC. Available at http://pdf.wri.org/factsheets/factsheet_are_you_ready_for_the_lacey_act.pdf.

Fletcher, R., P. Adams and S. Radosevich. 2001. Comparison of two forest certification systems and Oregon legal requirements. Oregon State University College of Forestry. Oregon State University Extension Service.

Fletcher, R., M. Rickenbach and E. Hansen. 2002. Forest certification in North America. Oregon State University Extension Service. Fraser, S.J. 2007. Filling a public policy gap in Canada: forest certification. The Forestry Chronicle 83(5): 666-671.

FSC-Canada. 2004. National Boreal Standard. Available at http://www.fsccanada.org/docs/39146450F65AB88C.pdf.

Gale, F. 2002. The politicisation of market instruments for ecological sustainability: The case of Voluntary Forest Certification in Canada. Australian National University, Canberra.

Gale, R. and F. Gale. 2006. Accounting for social impacts and costs in the forest industry, British Columbia. Environmental Impact Assessment Review 26(2): 139-155.

Government of Canada. 2010. Planning for a sustainable future: A federal sustainable development strategy for Canada. Government of Canada, Sustainable Development Office, Environment Canada, Ottawa. Available at http://dsp-psd.pwgsc.gc.ca/collections/collection_2010/ec/En4-136-2010-eng.pdf.

Government of Prince Edward Island. 2010. Province pursues forest certification [online]. Available at http://www.gov.pe.ca/news/ index.php3?number=news\&dept $=$ \&newsnumber $=7311$ \&lang $=\mathrm{E}$.

Gulbrandsen, L.H. 2004. Overlapping public and private governance: Can forest certification fill the gaps in the global forest regime? Global Environmental Politics 4(2): 75-98.

Gulbrandsen, L.H. 2005. The effectiveness of non-state governance schemes: a comparative study of forest certification in Norway and Sweden. International Environmental Agreements: Politics, Law and Economics 5(2): 125-149.

Haener, M. K. and M. K. Luckert. 1998. Forest certification: economic issues and welfare implications. Canadian Public Policy XXIV(2): 83-94.

Hansen, E. 1997. Forest certification and its role in marketing strategy. Forest Products Journal 47(3): 16-22.

Hickey, G.M. 2004. Regulatory approaches to monitoring sustainable forest management. International Forestry Review 6(2): 89-98. Hickey, G.M., J.L. Innes and R.A. Kozak. 2007. Monitoring and information reporting for sustainable forest management: a regional comparison of stakeholder perceptions. Journal of Environmental Management 84: 572-585.

Hickey, G.M., J.L. Innes, R.A. Kozak, G.Q. Bull and I. Vertinsky. 2005. Monitoring and information reporting for sustainable forest 
management: An inter-jurisdictional comparison of soft law standards. Forest Policy and Economics 209(3): 237-259.

Howlett, M., J. Rayner and C. Tollefson. 2009. From government to governance in forest planning? Lessons from the case of the British Columbia Great Bear Rainforest initiative. Forest Policy and Economics 11 (5-6): 383-391.

IBM Business Consulting Services. 2003. A greenward shift in the markets for forest products from British Columbia. IBM Corporation. Available at http://www.greenpeace.org/raw/content/canada/ en/documents-and-links/publications/a-greenward-shift-in-themarke-2.pdf.

Ice, G., L. Dent, J. Robben, P. Cafferata, J. Light, B. Sugden and T. Cundy. 2004. Programs assessing implementation and effectiveness of state forest practice rules and BMPs in the West. Water, Air, \& Soil Pollution 4(1): 143-169.

Klingberg, T. 2003. Certification of forestry: a small-scale forester perspective. Small-scale Forest Economics, Management and Policy 2(3): 409-421.

Leslie, A. D. 2004. The impacts and mechanisms of certification. International Forestry Review 6(1): 30-39.

Lister, J. 2009. Co-regulating corporate social responsibility: Government response to forest certification in Canada, the United States and Sweden. (Doctoral Dissertation). University of British Columbia, Vancouver, BC. 375 p.

Marshall, R.S., M. Cordano and M. Silverman. 2005. Exploring individual and institutional drivers of proactive environmentalism in the US wine industry. Business Strategy and the Environment 14: 92-109.

May, P. 2006. Forest certification in Brazil. In B. Cashore, F. Gale, E. Meidinger and D. Newsom (eds.). Confronting sustainability: Forest certification in developing and transitioning countries. pp. 337-362. Yale University Press, New Haven, CT.

Miller, R.J. and C. Nelson. 2003. Development of a criteria and indicators framework in Ontario [online]. Available at http://www.fao.org/DOCREP/ARTICLE/WFC/XII/0390-B1.HTM. [MRNFQ] Ministère des Ressources naturelles et de la Faune du Québec. 2010. La certification des forêts publiques québécoises Étude de faisabilité. Gouvernement du Québec, Ministère des Ressources naturelles et de la Faune, Direction de l'environnement et de la protection des forêts. Available at http://www.mrnf.gouv.qc .ca/publications/forets/evolution/certification-forets.pdf.

Nash, J. and J. Ehrenfeld. 1997. Codes of environmental management practice: assessing their potential as a tool for change. Annual Review of Energy and Environment 22: 487-535.

[NBDNR] New Brunswick Department of Natural Resources. 2004. Staff review of the Jaakko Pöyry report New Brunswick Crown forests: Assessment of stewardship and management. New Brunswick Department of Natural Resources, Fredericton, NB. Available at http://www2.gnb.ca/content/dam/gnb/Departments/ nr-rn/pdf/en/Publications/Jaakko_Poyry_FINAL.pdf.

Ontario Ministry of Finance. 2009. Supply chain guideline. Available at http://www.fin.gov.on.ca/en/bpssupplychain/documents/ scg_1-0.pdf.

[OMNR] Ontario Ministry of Natural Resources. 2004. Ontario promotes forest certification. Available at http://www.scc.ca/newsevents/news/article?classPK=news-ontario-promotes-forest-certification [Accessed November 28, 2011].

Overdevest, C. and M.G. Rickenbach. 2006. Forest certification and institutional governance: an empirical study of forest stewardship council certificate holders in the United States. Forest Policy and Economics 9(1): 93-102.

Owari, T., H. Juslin, A. Rummukainen and T. Yoshimura. 2006. Strategies, functions and benefits of forest certification in wood products marketing: Perspectives of Finnish suppliers. Forest Policy and Economics 9(4): 380-391.
Potoski, M. and A. Prakash. 2004. Regulatory convergence in nongovernmental regimes? Cross-national adoption of ISO 14001 certifications. The Journal of Politics 66(3): 885-905.

Prakash, A. 1999. A new-institutionalist perspective on ISO 14000 and Responsible Care. Business Strategy and the Environment 8: 322-335.

Rametsteiner, E. 2002. The role of governments in forest certification - a normative analysis based on new institutional economics theories. Forest Policy and Economics 4: 163-173.

Ramsay, D. 2004. Connecting state/ provincial forest policy with certification. Ontario perspective. The Frontiers of Forest Certification. Fifth Certification Watch Conference, Vancouver, BC.

Skjærseth, J.B., O.S. Stokke and J. Wettestad. 2006. Soft law, hard law, and effective implementation of international environmental norms. Global Environmental Politics 6(3): 104-120.

Smart, B. (ed.). 1992. Beyond compliance: a new industry view of the environment. World Resources Institute, Washington, DC. 285 p. Snyder, F. 1993. The effectiveness of European community law: institutions, processes, tools and techniques. The Modern Law Review 56(1): 19-54.

Steurer, R., G. Berger, A. Konrad, and A. Martinuzzi. 2007. Sustainable public procurement in EU member states: Overview of government initiatives and selected cases. Vienna University of Economics and Business Administration, Vienna. Available at http:// www.sustainability.at/pdf/csr/Sustainable $\% 20$ Public\%20Procurement\%20in\%20EU\%20Member\%20States_Final\%20Report.pdf.

[SFI] Sustainable Forestry Initiative. 2010a. Section 2. Sustainable Forestry Initiative 2010-2014 Standard. Sustainable Forestry Initiative Inc. Available at http://www.sfiprogram.org/files/pdf/Section2 sfi_requirements_2010-2014.pdf.

. 2010b. Section 6. Guidance to SFI 2010-2014 Standard. Sustainable Forestry Initiative Inc. Available at http://www.sfiprogram .org/files/pdf/Section6_sfi_requirements_2010-2014.pdf.

Sustainable Forestry Initiative Program. 2005. 2005 - 2009 SFI Standard and verification procedures. American Forest \& Paper Association, Washington, DC. Available at

http://www.sfiprogram.org/files/pdf/sfi-standard-2005-2009sept $\% 2008 \% 20$ update.pdf [Accessed November 28, 2011].

Tikina, A.V. 2008. Forest certification: are we there yet? CAB Reviews: Perspectives in Agriculture, Veterinary Science, Nutrition and Natural Resources 3(18): 8.

Tikina, A.V. and J.L. Innes. 2008. A framework for assessing the effectiveness of forest certification. Canadian Journal of Forest Research 38(6): 1357-1365.

Tollefson, C., F. Gale and D. Haley. 2008. Setting the standard: certification, governance and the Forest Stewardship Council. UBC Press, Vancouver, BC. 404 p.

U.S. Green Building Council. 2009. New construction and major renovations. Available at http://www.usgbc.org/ShowFile.aspx?DocumentID $=5546$

UNECE/FAO. 2005. Forest certification - Do governments have a role? UNECE/FAO Timber Branch, Geneva, Switzerland. Available at http://www.unece.org/fileadmin/DAM/timber/docs/dp/dp-44.pdf. Upton, C. and S. Bass. 1996. The forest certification handbook. St. Lucie Press, Delray Beach, FL. 218 p.

Vidal, N. and R.A. Kozak. 2008. Corporate responsibility practices in the forestry sector: Definitions and the role of context. Journal of Corporate Citizenship 31: 59-75.

Vlosky, R. P. 2000. USDA Forest Service, Bureau of Land Management, and state forester perspectives on certification. Forest Products Journal 50(3): 21-27.

Vogt, K., B. Larson, J. Gordon, D. Vogt and A. Fanzeres (eds.). 2000. Forest certification: roots, issues, challenges and benefits. CRC Press LLC, Boca Raton, FL. 374 p. 